\title{
"O POVO CATÓLICO TAMBÉM TEM AXÉ": A ESTÉTICA POP BRASILEIRA E A INCULTURAÇÃO CARISMÁTICA
}

\author{
Evandro de Sousa Bonfim ${ }^{I}$
}

Resumo: $\mathrm{O}$ artigo busca mostrar como artistas ligados à Renovaçáo Carismática Católica lidam com o tema da inculturaçáo, buscando nas fontes da cultura de massa brasileira elementos para a composiçáo de uma estética religiosa pop centrada na transmissão do Espírito Santo através das mídias. O exemplo tratado é o da cantora de axé cristáo Jake, que, através de imagens, letras, acompanhamento musical e adoçáo da fala regional nordestina, se transforma na figura da baiana, procurando assim produzir uma mensagem cristá brasileira e promover a diversificaçáo interna do movimento carismático.

Palavras-chave: Renovação Carismática; Cristianização; Música Católica.

Abstract: The paper aims to show how artists linked to the Catholic Charismatic Renewal deal with the issue of inculturation, basing their artwork in Brazilian mass culture repertory, thus creating a religious pop aesthetic centered on the transmission of the Holy Spirit through the media. The analysis focuses on the carrier of Jake, a singer of regional rhythms who - through images, lyrics, musical production and adoption of northeastern accent - becomes a baiana, in order to convert Christian message into Brazilian cultural language as well as diversifying the Charismatic movement in the country.

Keywords: Charismatic Renewal; Christianization; Catholic Music.

1 Doutor em Antropologia Social. Pesquisador do Departamento de Antropologia do Museu Nacional - Universidade Federal do Rio de Janeiro. Contato: evandrobonfim@hotmail.com 


\section{INTRODUÇÃO}

"Você tem que tomar uma overdose de Jesus Injetar na sua veia o sangue que correu da cruz" Jake

"O povo católico também tem axé". A frase, da cantora de "axé cristão" $\mathrm{Jake}^{2}$, pode soar banal para quem acompanha como as formas de religiosidade contemporâneas tangenciam continuamente os domínios considerados "profanos". Mas trabalhar com a simples hipótese de que é cada vez mais tênue (ou mesmo inexistente) a linha separando os empreendimentos sagrados daqueles seculares significa adotar a perspectiva de observadores externos ao circuito de produção, divulgação e recepção de conteúdos religiosos,

$2 \mathrm{O}$ presente artigo se baseia em entrevista pessoal realizada com a cantora Jake em sua residência na Zona Sul de Sáo Paulo, no âmbito do projeto maior de uma pesquisa realizada entre 2009 e 2011 com a comunidade carismática católica Cançáo Nova (Bonfim, 2012). Ainda hoje a cantora Jake tem sido participante assídua dos eventos da Cançáo Nova, encaixando-se no perfil de "colaboradora”, como o Padre Fábio de Melo, ou seja, não integrantes da comunidade que ajudam a compor os conteúdos evangelizadores das mídias da Canção Nova. Como apoio, serão usadas letras de músicas, fichas técnicas, participaçóes em programas de televisáo e entrevista concedida ao autor para a apreciação da imagética mobilizada pela cantora. Jake participa do ministério musical "Guerreiros do Amor" desde os 15 anos, cantando e tocando instrumentos. A paróquia que frequenta pertence à diocese de Santo Amaro, na cidade de São Paulo, próxima ao Santuário do Terço Bizantino, comandado por outro nome importante da Renovação Carismática brasileira, o padre Marcelo Rossi. Em 2006, ela lança o primeiro CD solo, intitulado Guerreira do Amor. Em 2008, aparições cantando a música "Pó pará com pó" no site de vídeos YouTube fazem dela uma celebridade virtual, tornando-a campeá de acessos na rede e merecendo comentário no blog Obra em Progresso, do cantor Caetano Veloso. Depois, Jake é convidada para inúmeros programas de TV não católicos e chega a cantar no trio elétrico de Ivete Sangalo no carnaval fora de época realizado em Natal. Atualmente, a cantora acaba de lançar o terceiro CD, "Esperança”, focado na axé music e em outros ritmos nordestinos como o forró, presente na faixa "Sem Jesus Não Vai", cantada em parceria com a paraibana Elba Ramalho.

Debates do NER, Porto Alegre, ano i6, N. 28, P. 37-68, Jul./Dez. 20 i 5 
desconsiderando como os próprios emissários concebem (no sentido de refletir sobre e criar) as mensagens que transmitem. O objetivo deste artigo é investigar o que orienta, como se configura e através de que meios se realiza a transmissão do Cristianismo praticado por Jake. Esta análise privilegiará as imagens utilizadas pela ministra de louvor em encartes de $\mathrm{CD}$, em vídeos da internet e no site pessoal, que, conjugados com a música e as apariçóes midiáticas, constituem a proposta de evangelizaçáo da cantora, representante da mais recente fase do catolicismo carismático.

Em primeiro lugar, é interessante retomar a frase citada anteriormente e proferida por Jake no programa "Vozes da Igreja", da TV Aparecida (08/11/2008): "o povo católico também tem axé". Tal declaração dificilmente seria feita por um evangélico pentecostal, por exemplo ${ }^{3}$. Isto porque a noção de axé, mesmo que no caso mediada pela axé music (música popular baiana surgida na segunda metade da década de 1980), provém de religiōes de matriz africana, como o Candomblé. Religióes afro-brasileiras, juntamente com a Umbanda, têm sido alvo da chamada "teologia da batalha espiritual" (cf. Silva, 2007) e da "demonizaçáo" (nos termos da traduçáo simbólica envolvendo a transformação de deuses tradicionais em demônios na cristianização de povos nativos, cf. Meyer, 1999).

Historicamente, a Igreja Católica sempre esteve à frente da perseguição aos cultos afro-brasileiros, ao mesmo tempo em que servia de fonte para a composiçáo de expressóes devocionais, rituais e até mesmo doutrinais destas mesmas religiosidades, sobretudo da Umbanda, dentro do que se costuma chamar de sincretismo ${ }^{4}$. No entanto, há uma importante inflexáo no trato

3 Embora cantores evangélicos adaptem músicas de axé para o estilo gospel, como é o caso de "I miss her", do Olodum, cuja versáo evangélica foi feita por Lázaro, ex-vocalista do grupo de percussão baiano e atual membro da Igreja Batista, com o título "Eu sou de Jesus".

4 A Antropologia do Cristianismo proposta por Joel Robbins, preocupada com o tema da mudança cultural, reserva especial crítica à noçáo de sincretismo, que valorizaria mais a continuidade dos conteúdos, a partir da utilização de referentes mais aceitos socialmente, do que a transformação e criação que os processos de "sincretizaçáo" acarretariam (ver Robbins, 2004, sobretudo a conclusão). Gostaria de acrescentar que a noçáo de sincre-

Debates do NER, Porto Alegre, ano i6, N. 28, P. 37-68, Jul./Dez. 2015 
que o Catolicismo no Brasil e no mundo costuma dispensar não só às religiosidades africanas, mas a toda pluralidade cultural, a partir do Concílio Vaticano II (1962-1965), que, dentre outras inovaçóes, promove a vernacularização da liturgia e de outros documentos da Igreja, além de abrir espaço para elementos da cultura local nas missas, sobretudo no que diz respeito à música e aos elementos visuais (Miranda, 2001). É justamente no âmbito da Teologia da Inculturação que a cantora de axé cristão Jake se insere ${ }^{5}$.

\section{A GUERREIRA DO AMOR: ALEGRIA E AXÉ}

Mas como Jake descreve a música que faz? "Acreditamos que para evangelizar jovens é preciso falar a linguagem deles. Além disso, sempre admirei a MPB e ritmos regionais. Como meu timbre vocal me conduziu ao axé e o ministério Guerreiros do Amor, do qual participo, sempre teve carisma desbravador e ousado, Deus uniu tudo isto num CD de Axé Cristáo. É um tempo novo na igreja, em que o jovem e o leigo sáo usados por Deus na mídia, no mundo e nos confins", conta.

Assim, para ela, não há separação entre a concepção de carreira musical e a evangelizaçáo. A evangelizaçáo proposta por Jake diz respeito ao princípio de abertura para a alteridade do Cristianismo, envolvendo transmissáo de conteúdos e alteração dos comunicadores. A eficácia da evangelização não

tismo também obscurece as modificaçóes ocorridas no próprio Cristianismo em contato com outras matrizes religiosas e culturais.

5 A Teologia da Inculturação surge em meados da década de 1970 no âmbito da crítica católica à ação evangelizadora tradicional, de cunho catequético e associada ao poder colonizador. Procura retomar a questáo da missionarizaçáo de conteúdos universais diante da diversidade cultural através de conceitos como "encarnação", que estabelecem a possibilidade de revelaçóes evangélicas não estarem cir cunscritas à Bíblia, mas igualmente presentes nas realidades indígenas. Sobre a gênese e as principais discussóes acerca da Teologia da Inculturaçáo, ver a tese de Rufino (2002, p. 280-320). Para um ponto de vista dos agentes religiosos da inculturaçáo, ver Miranda (2001).

Debates do NER, Porto Alegre, ano i6, N. 28, P. 37-68, jul./Dez. 20 i 5 
reside necessariamente no proselitismo, mas na realização de uma comunicação sensibilizadora ${ }^{6}$.

Enquanto as iniciativas mais visíveis da inculturação católica dizem respeito às culturas fora da tradição ocidental, Jake se propóe a evangelizar a juventude, o que implica "falar a linguagem deles". Tanto quanto os grupos não cristãos, ocidentais afetados pelo secularismo e cristãos nominais constituem público evangelizável para o Catolicismo (ver $\$ 55$ e $\$ 56$ da Evangelii Nutiandi). Segundo Jake, os jovens atuais estáo precisamente nesta esfera de influência, imersos no "nadismo" ou na indiferença a valores externos ao cotidiano imediato. "O jovem hoje se preocupa com malhação, lipoaspiração e azaração. Nosso desafio é inserir conteúdo nestas vidas e fazê-los formar opiniáo", afirma.

Mas como atingir esta faixa etária, de forma a comunicar-se através de signos que sejam ao mesmo tempo apreensíveis e convocadores? Jake comenta que, comercialmente, teria sido mais vantajoso para ela se dedicar ao forró. Mas, segundo a própria cantora, características pessoais (o timbre de voz, a personalidade espontânea) e a escolha do público-alvo a ser evangelizado levaram-na a cantar axé e ritmos associados.

Segundo o documento Pastoral Afro-Brasileira da Confederação Nacional dos Bispos do Brasil (2002, p. 27), "o AXÉ é a energia vital. A fonte do AXÉ está no Deus da Vida, Senhor Absoluto de toda a criação”. As principais fontes do axé evocado pela ministra de louvor, no entanto, estáo na já citada axé music, que tem como marco de surgimento o ano de 1985, com o

6 Para Latour (2004), a enunciaçáo religiosa náo tem a ver com o transporte de informaçáo, mas com a transformaçáo daqueles que trocam a mensagem, no sentido de que esta deve ser proferida de forma a suscitar "uma alteração da pulsação e do andamento da experiência" (a noçáo grega de kairos). No caso do Cristianismo, o regime enunciativo religioso é marcado pela evangelização, que está relacionada ao ímpeto comunicacional e à maneira de se transmitir a mensagem das boas-novas. "A religiáo, ao menos na tradiçáo a partir da qual falarei - a saber, a cristã -, é um modo de pregar, de predicar, de enunciar a verdade [...] Esta é literalmente, tecnicamente, teologicamente uma forma de dar a notícia, de trazer a 'boa-nova', o que em grego se chamou 'evangelios'” (p. 350).

Debates do NeR, Porto Alegre, ano i6, N. 28, P. 37-68, Jul./Dez. 20 i 5 
"fricote" de Luiz Caldas. Jake está no âmbito da interdiscursividade ao extrair da palavra axé as significaçóes básicas de força dinâmica e alegria vital que pode ser infundida/transmitida/trocada, sentido que pode ser comportado (a partir de uma apropriaçáo criativa) tanto pelo contexto religioso (africano e inculturado) como pelo da música pop (baiana) ${ }^{7}$.

Muitas cançóes de axé music tratam a alegria como algo que estava contido e pode finalmente irromper através daquele momento de celebraçáo, fazendo com que os sentimentos negativos se dissipem:

Extravasa, libera e joga tudo pro ar

Eu quero ser feliz antes de mais nada

Claudia Leitte

Aquele grito que estava preso na garganta se transformou

E a nossa vibraçáa é tanta, cante comigo Pra dizer a todo mundo que este nosso amor

É o bicho, é o bicho

Ricardo Chaves

Eu disse

Bota pra ferver, no caldeirão do amor

Bota pra ferver, a ilusão e a dor

7 Há na superfície linguística da música de Jake a combinação de várias palavras denotando qualidades similares às do axé, igualmente de forma interdiscursiva, como carisma (tanto no sentido de personalidade carismática como no sentido mais estritamente religioso, de ter recebido o dom de Deus para evangelizar musicalmente, conforme será visto mais à frente) e shekinah, palavra hebraica para expressar a presença de Deus entre os homens, sentida de forma dinâmica e sensível através do Espírito Santo. Todas parecem envolver um circuito de troca espiritual que inclui transferências entre as pessoas divinas, os evangelizadores e o público, de forma a criar e manter a mobilizaçáo corporal/anímica da experiência cristã. Sobre a troca de constituintes pessoais no âmbito da relaçáo entre humanos e entidades espirituais no Cristianismo, ver o instigante texto de Mark Mosko sobre as relaçóes entre a noçáo de pessoa partível melanésia e cristá (2008).

Debates do NER, Porto Alegre, ano i6, N. 28, P. 37-68, Jul./Dez. 20 i 5 
Bota pra ferver, o rio de lágrimas Asa de Águia \& Ivete Sangalo

Liberando geral Dá-lhe alegria, louvor e glória

Com o grito da galera É mais um na rede É a vitória Jake

Esta proposta celebrativa é importante para o tipo de evangelização de Jake. Ela é apresentada da seguinte forma em release para a imprensa: "a bagagem profissional, beleza e talento fazem desta jovem um ícone para a juventude atual, pois além de ser comunicativa e espontânea, Jake canta a beleza da vida, a força para lutar e a alegria. Amante das percussóes e swing brasileiro, ela interage com o público contagiando de forma excitante". As fotografias do encarte do $\mathrm{CD}$ e de shows são instantâneos desta disposição vital/artística assumida pela cantora: 
Fotos 1 e 2 - Instantâneo de show e encarte do $1^{\circ}$ álbum de Jake
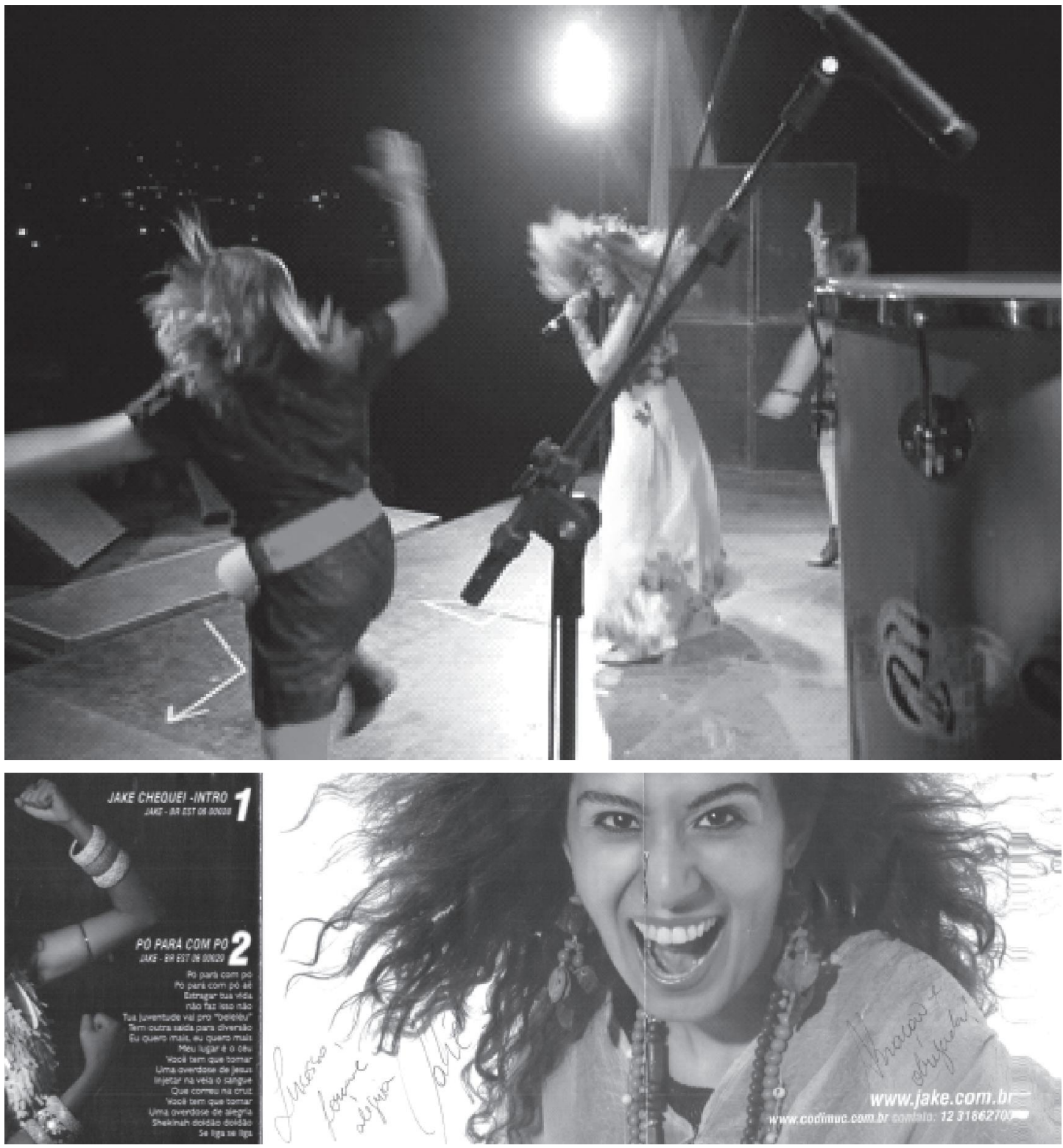

"Efusão" é um dos termos usados pelo Catolicismo para descrever a experiência com o Espírito Santo. A alegria está listada entre os frutos do Espírito.

$\mathrm{Na}$ medida em que atualidade e alegria são características atribuídas aos jovens, a baixa intensidade (mais do que a falta em si) destes componentes nas expressôes litúrgicas, musicais e comunicacionais torna as mensagens católicas pouco atrativas para esta faixa da população. Este parece ser o pano

Debates do NER, Porto Alegre, ano i6, n. 28, P. 37-68, Jul./Dez. 20 i 5 
de fundo das colocaçóes da cantora sobre o "carisma desbravador e ousado" do ministério musical do qual ela participa e sobre "o tempo novo na Igreja", entrevisto mediante tais manifestaçóes. Jake está aqui se juntando à corrente de mobilizaçóes carismáticas em busca de novos recursos expressivos para o Catolicismo, com vistas a renovar a Igreja, sobretudo através da linguagem e da participação de grupos que não pertencem à hierarquia católica e nem atendem aos critérios usuais de autoridade: as mulheres, os leigos e os jovens ${ }^{8}$.

Diane Austin-Broos (1997), em rica etnografia sobre o Pentecostalismo popular jamaicano, mostra como a perspectiva moralizante do Cristianismo de origem protestante contrasta com a presença, nas populaçóes de origem africana, do eudemonismo, ou seja, da busca da felicidade como disposiçáo vital primária. Contudo, conforme mostra a autora, a orientação eudemonística se faz ativa nas congregaçóes jamaicanas, sobretudo entre as mulheres, através da música, das danças e dos rituais de cura. Birgit Meyer, em trabalho citado anteriormente, também enfatiza que a concepção de mal africana está relacionada com forças (externas) que ameaçam a fruiçáo da vida, o principal valor entre os Ewe, por afetar a saúde, a fertilidade e a riqueza, enquanto que o mal, para os missionários pietistas, localizava-se no interior das pessoas, exigindo autoexame e arrependimento (o processo de "becoming sinners" que os Urapmin estudados por Robbins, 2004, vivem tão agudamente e que só parece se atenuar com a possessão coletiva e dançante pelo Espírito Santo chamada de "Spirit Disko").

Porém, Jake parece não tocar exatamente na questão do "tormento moral" (para usar outra expressáo de Robbins). Ela se dirige mais precisamente à opacidade dos conteúdos destinados aos jovens (mas não somente a eles) e à falta de entusiasmo das práticas católicas tradicionais. A própria cantora

8 Outros protagonistas carismáticos também salientam o ineditismo propiciado pelos atuais carismas suscitados pelo Espírito Santo. "A Canção Nova é feita para contribuir na renovaçáo da Igreja. A Cançáo Nova traz o novo", afirma o monsenhor Jonas Abib, fundador da Canção Nova, comunidade cujo carisma é a evangelização midiática. Cabe aqui relembrar a já citada crítica que Joel Robbins (2007) faz à valorização da continuidade no pensamento antropológico, principalmente no que diz respeito ao Cristianismo.

Debates do NER, Porto Alegre, ano i6, N. 28, P. 37-68, Jul./Dez. 20 i 5 
afirma que o lançamento do CD Guerreira do Amor trouxe ao público "uma atitude revolucionária, se comparado aos padróes católicos”. É essencial lembrar que a alegria é um dos frutos do Espírito Santo (Gálatas 5:22). Portanto, sentir-se alegre na Igreja é uma manifestação carismática que não pode estar ausente da experiência cristã católica. Mais do que isso, a alegria é sinal do shekinah, a presença divina através do Espírito Santo, a dimensão partível da pessoa de Deus (ou a pessoa trinitária que em si é partível) que se destaca para entrar na constituição da pessoa cristá. Conforme mostra a faixa 4 do álbum, intitulada "Bom é louvar":

Bom é louvar o nosso Deus, Bom é louvar, bom é louvar E quando Ele vem, vem, vem $\mathrm{O}$ teu Espírito fica aqui E quando Ele vem, vem, vem Nos enche de alegria, amor e paz ${ }^{9}$

A alegria também é o tema do maior sucesso de Jake, "Pó pará com pó":

Pó pará com pó, Pó pará com pó aê Estragar tua vida Não faz isso não Tua juventude vai pro beleléu Tem outra saída para a diversão Eu quero mais, eu quero mais Meu lugar é o céu Você tem que tomar uma overdose de Jesus

9 Nas missas carismáticas, como as de cura e libertação, as diversas presenças divinas (de Maria, do Jesus eucarístico, dos anjos, do Espírito Santo) são acolhidas com palmas efusivas, em sinal não apenas de reverência, mas também de júbilo.

Debates do NER, Porto Alegre, ano i6, N. 28, P. 37-68, JUl./Dez. 20 i 5 
Injetar na veia o sangue que correu na cruz Você tem que tomar uma overdose de alegria Shekinah doidão, doidão Se liga, se liga

O recado para os consumidores de drogas (de que eles precisam "parar com o pó") náo é dado mediante argumentos morais, sob a forma, por exemplo, de admoestaçáo ao abandono da conduta pecaminosa. Conforme a própria cantora diz, suas cançóes "são músicas que valorizam a vida". As drogas vão precisamente "estragar" a vida e fazer com que a juventude da pessoa vá para o "beleléu". Mas, ao abdicar das drogas, os usuários não vão ficar privados de divertimento ("tem outra saída para a diversáo"). No lugar das drogas, há uma opçáo celestial e, portanto, superior: os ouvintes são estimulados a tomar "uma overdose de Jesus", que significa tomar uma "overdose de alegria", portanto trata-se de uma experiência de grande intensidade, de êxtase e com registro no corpo $^{10}$.

O sangue vivificador de Cristo, o qual os cristãos são tradicionalmente convidados a beber, deve ser "injetado na veia". O resultado é a sensaçáo corpórea e incorporada da presença divina, que pode sobrevir ao "doidáo", bastando que ele táo somente fique atento ou "ligado" na oportunidade ("Shekinah doidão, doidão, se liga, se liga").

É bom atentar para o fato de que os deslizamentos de sentido produzidos por Jake, buscando expressóes do mundo das drogas para descrever práticas

10 Sahlins (1996) comenta a passagem, na cosmologia ocidental, do dolorismo cristão para o hedonismo propiciado pelas práticas de consumo capitalistas. A atitude promovida por Jake se distancia também do dolorismo, pois prega Jesus como infundindo alegria e curando "quem tocar no seu manto". No entanto, o resultado parece estar mais próximo do eudemonismo do que do hedonismo, que visa à satisfaçáo individual e imediata. É justamente como transcendência a este hedonismo contemporâneo (simbolizado pela trindade "azaraçáo, malhaçáo e lipoaspiraçáo") que a mensagem da cantora quer se inserir na vida dos jovens. "A nossa alegria, a nossa energia canalizada para a coisa certa é um sucesso", afirma ela, náo excluindo o direcionamento do entusiasmo espiritual, que deve, no entanto, conduzir à vida exuberante implícita na palavra "sucesso".

Debates do NER, Porto Alegre, ano i6, N. 28, P. 37-68, Jul./Dez. 20 i 5 
religiosas centrais do Cristianismo católico, como a comunhão ("comei da minha carne, bebei do meu sangue"), são, no mínimo, polêmicos. Esta prática linguística é efetivamente uma (tentativa de) tradução. No encarte do $\mathrm{CD}$, há uma espécie de aviso: "músicas em linguagem coloquial". Jake não só é autora das letras das canções como também participa da criação dos arranjos. Ela afirma o seguinte sobre o processo de composição: "as letras das minhas músicas são inspiraçóes de Deus. O Senhor deseja que todos entendam facilmente suas mensagens. Estamos nos fins dos tempos, por isto é preciso anunciar. Ninguém poderá dizer que nunca ouviu falar de Jesus”. Conforme dito anteriormente, sem o componente náo interiorizante, mas exteriorizante, da evangelizaçáo, é impossível compreender não só a carreira de Jake, mas também a maioria das manifestaçóes cristâs.

Assim, a música de Jake é carismática (acontece sob inspiração divina) e procura contribuir para uma transmissão amplificada dos conteúdos cristãos. Todos devem ter acesso às boas-novas na forma que lhes for mais comunicável. Os recursos expressivos da mensagem cristá não podem depender exclusivamente do ponto de vista do emissor. A própria cantora comenta o seguinte sobre seu trabalho: "meu trabalho é missionário porque o trabalho missionário está para o outro". A mensagem cristã não é universal em si nesta perspectiva. Não há um protocolo padrão, por isso não se pode falar de cristianização sem a análise das práticas específicas de evangelizaçáo, que sáo antes de tudo discursivas, ocorrendo através das mais diversas materialidades e mediaçóes (Meyer, 2006).

A "obra nova" da qual o ministério musical de Jake participa é urgente, pois já se está vivendo o "fim dos tempos". Assim, o que aparece como sendo algo eminentemente secular está na verdade motivado por ideias milenaristas. E a afirmação "ninguém poderá dizer que não ouviu falar de Jesus" não é quantitativa, mas qualitativa: as pessoas vão ter oportunidade de ouvir falar de Jesus no "idioma" que lhes é significativo, tanto no registro linguístico como no cultural. Para os jovens que gostam de música brasileira dançante, Jake prega no trio elétrico. Há casos de folióes convertidos 
durante micaretas com participaçấo da cantora, conforme mostra o seguinte testemunho extraído de seu site:

Boa tarde Jake, como vai? Meu nome é... tenho 29 anos fui usuário de cocaína 4 anos da minha vida. Estava no Carnatal [carnaval fora de época da capital nordestina Natal, realizado todo mês de dezembro] acompanhando os trios elétricos, para falar a verdade neste dia estava muito loco $[s i c]$ lá. Tinha cheirado um monte de pó. Fiquei táo louco que eu andava muito mais rápido do que o trio. Pois bem por coincidência tive uma lesáo muscular (acho que foi por conta do Pó) que me fez parar por alguns minutos, quando me dei por mim estava de frente para o trio da Ivete [Sangalo, pop star da axé music]. Justamente neste momento você subiu em cima do trio. Mal conseguia ouvir o que as pessoas falavam eu realmente estava bem louco, cheirei tanto pó que uma pessoa normal morreria de overdose. Algo de mágico aconteceu, no momento que você começou a cantar meus ouvidos se abriram comecei a entender perfeitamente a música não sei o que aconteceu, mas chorei tanto que tive que abandonar a festa. Nunca tinha me acontecido, mas o efeito da cocaína cessou na hora. Fui para casa ainda chorando sem saber ainda... Fui para casa sem saber ainda o que estava acontecendo. Eu ainda tinha muito pó no meu bolso, mas nesse momento uma força tomou conta de mim e me ajoelhei no meio do meu quintal e pedi a Deus que náo me deixasse mais eu me drogar, eu náo queria mais estragar a minha vida (exatamente como diz a sua música) chorei muito nesta noite, logo quando amanheceu o dia joguei toda a droga que estava comigo na privada, e acredite, nunca mais tive vontade de usar droga. Eu disse nunca mais. Eu fiz uma coisa que eu nunca tinha feito na minha vida. Entrei numa igreja me ajoelhei e orei a Deus. Perguntei para uma senhora se existia algum padre para eu poder conversar com ele. Encontrei com o padre falei o que aconteceu e ele me acolheu muito bem. Vou ser batizado no dia 18/01 e começarei a catequese para fazer a primeira comunhão. Tentei ligar para você, mas náo consegui, tentei passar e-mail, mas meus e-mails estáo voltando, achei seu blog e agora espero que você leia isso. Estou muito feliz, sou um novo homem.

A conversão como convicção íntima não está de maneira nenhuma em jogo no relato. A conversão do jovem micareteiro se realiza através de um acontecimento inexplicável: o término do turvamento mental, sensorial e motor causado pela droga em virtude da voz da missionária que, 
literalmente, pregava entre pagãos modernos que celebravam o carnaval. Outros eventos considerados incompreensíveis ou inusitados pelo narrador (os quais se enquadrariam na categoria cristã de "miraculoso") também acontecem, como a não ocorrência da overdose, o súbito fim do efeito da cocaína, o choro, a força exterior que o impele a orar, fazendo-o vencer a compulsão e descartar a droga que ele ainda tinha consigo, e a ida à igreja. $\mathrm{O}$ fato ocorreu em um dos pontos altos da carreira de Jake, quando uma das mais bem-sucedidas cantoras brasileiras da atualidade, Ivete Sangalo, convidou a ministra de louvor para subir em seu trio na micareta de Natal, em dezembro de 2008. A apresentaçáo de Jake ao lado de Ivete teve grande repercussão na mídia, levando a música "Pó pará com pó" a ser um dos hits do carnaval baiano de 2009.

É interessante o quanto os veículos que conduzem a cristianização do jovem (que ainda náo havia sido batizado) estáo carregados de ambiguidade: 1) o torpor da droga, que o leva a parar para ouvir a voz de Jake e sob o qual a maior parte dos eventos inexplicáveis estáo referidos e 2) a missionária carnavalesca, atuando no limite da linha que supostamente separa o Cristianismo do paganismo. A droga se mostra tanto tática infernal como produtora de certa circunstância corporal e emocional que permite a manifestaçáo divina, como mostra o testemunho. $\mathrm{O}$ caso desse jovem não é isolado. Uma grande figura do movimento carismático, o falecido fundador da comunidade Bethânia, padre Léo, narra que sua conversáo, não só ao Catolicismo dos pais, mas ao sacerdócio, aconteceu durante o estado de intoxicação provocado pela maconha, quando lhe apareceram visóes de santos e anjos. $\mathrm{O}$ êxtase da droga, demoníaco, pode assim ser revertido em êxtase divino, que dispensa as mediaçóes psicotrópicas. Incorporar tais experiências, imagens e linguagem relativas ao mundo das drogas certamente significa uma maneira ousada de coloquializar a mensagem cristá. Mas agora é interessante examinar mais a fundo as relaçóes entre a mensagem coloquial e festiva proposta por Jake e o universo pop-religioso mobilizado pela axé music e por outros ritmos percussivos afro-brasileiros. 


\section{"QUEM NÁO TEM BALANGANDÁS NÁO VAI NO BONFIM": O CRISTIANISMO BRASILEIRO}

Embora as referências e as composiçōes dos cantores e grupos de axé sejam variadas, a ligação com os blocos afro e os afoxés (que são considerados "o Candomblé na rua") é marcante. A base inicial do ritmo pop é justamente a conjunção de guitarras com o ijexá: o toque de percussão do afoxé, destinado primordialmente a Oxalá. E, conforme visto, a alegria cristã promovida por Jake náo é um sentimento genérico, mas se realiza visual e musicalmente através dos recursos expressivos da noçáo estendida de axé (pop e religiosa, africana e inculturada).

Em primeiro lugar, a cantora se propóe a recuperar "as raízes percussivas da música brasileira", mantendo um naipe de percussão permanente na formação da banda que a acompanha. Uma das preocupaçóes da reforma litúrgica do Vaticano II é precisamente abrir espaço para instrumentos e preferências melódicas locais, como a presença de tambores na missa inculturada afro. Esta parece ser também a preocupação de parte dos cantores católicos atuais, como o padre Fábio de Melo, que afirma também um retorno às raízes, porém da música sertaneja. Pode-se, assim, dizer que há um discurso culturalista presente nestes artistas que não era encontrado em nomes anteriores como Padre Marcelo Rossi, na década de 1990, e Padre Zezinho, pioneiro dos padres cantores no Brasil, com carreira iniciada na década de 1960.

A fim de seguir tal tendência, a paulistana católica Jacqueline se "converte" na "baiana" Jake. É bom lembrar que, no âmbito da axé music, as cantoras são quase que exclusivamente nascidas no estado da Bahia. Este "tornar-se baiana" inclui modificaçóes em registros corporais, como a voz. Segundo Jake, a alteraçáo vocal é facilitada por conta do seu timbre (grave como o de Ivete Sangalo e Claudia Leitte, dois grandes nomes femininos do ritmo), mas não é suficiente. Ela precisou mudar a pronúncia e a prosódia para cantar como alguém da regiáo Nordeste, onde a Bahia está localizada e cuja formação histórica regional compartilha. 
A produção musical do CD Guerreira do Amor esteve a cargo de Renno Saraiva e Carlos Henrique, que, segundo Jake, já trabalharam com o cantor Raimundo Fagner, natural de outro estado nordestino, o Ceará. Um dos conselhos dos produtores foi justamente uma correçáo na prosódia, fato comum na produção musical em geral e que objetiva a adequação da letra à métrica e ao ritmo (gerando aparentes "erros" de prosódia em muitas cançôes).

Um exemplo desta alteração, comentado pela própria cantora, está na faixa 3, intitulada "Pressáo". Segundo Jake, para pronunciar a palavra "Pressáo" segundo a fala "nordestina”, ela teve que deslocar o acento fonológico, transformando a palavra em paroxítona, e não só tornar a vogal "e" aberta, mas ampliar esta abertura ao máximo. Considerando-se que o português brasileiro é uma língua acentual, ou seja, conta com proeminências (os acentos, que podem ser de intensidade, altura e duração) que servem de referência para a melodia da língua, pode-se dizer que estes efeitos, repetidos em outros segmentos/palavras, geram modificaçóes prosódicas relevantes. As alteraçóes podem ser descritas conforme mostrado abaixo, através da Regra de Associaçáo de Acento. A comparação será feita entre $\mathrm{J}^{1}$, que corresponde à pronúncia "paulista" de Jake, e $\mathrm{J}^{2}$, a pronúncia "nordestina":

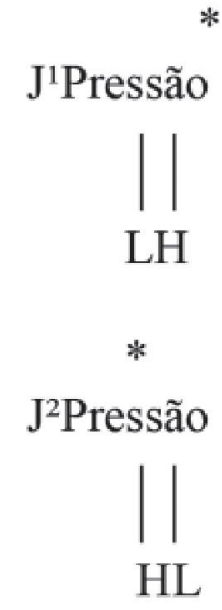

Debates do NER, Porto Alegre, ano i6, n. 28, P. 37-68, Jul./Dez. 20 i 5 
A abertura e/ou ampliação da intensidade da abertura da vogal ("e", no caso, mas também feita com "a" e "o") não apenas acompanha a modificaçáo do acento fonológico da palavra como também altera a frequência fundamental:

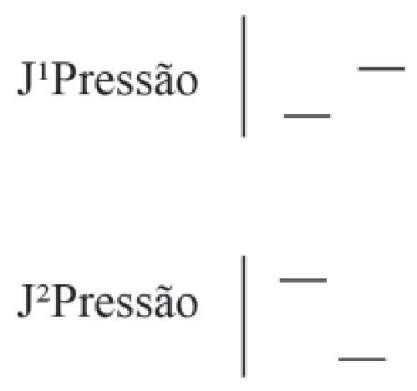

Em termos melódicos, $\mathrm{J}^{1}$ vai do baixo (L) para o alto $(\mathrm{H})$, mas isto ocorre, em termos do nível de voz, a princípio apenas com o aumento em um tom (da primeira sílaba com tom baixo para a sílaba acentuada com tom médio). Em J ${ }^{2}$ o movimento melódico é invertido de LH (ascendente) para HL (descendente), e a nova sílaba proeminente é no mínimo dois tons mais altos que a nova sílaba sem proeminência, produzindo a sensaçáo sonora da partiçáo da palavra.

A medida faz que a paulistana Jake fale como "nordestina" (através de características prosódicas que seriam compartilhadas pelos estados da região), bem como permite que seu canto se ajuste ao ritmo do axé, solidário a esta mesma prosódia regional. A impressão de naturalidade do resultado é variável, podendo inclusive soar como "hipercorreção" ou mesmo uma espécie de caricatura do sotaque nordestino. Náo obstante, muitas cantoras de axé trabalham no registro da hipercorreção do sotaque, mesmo na fala coloquial, possivelmente como forma de acentuar a "identidade" baiana. Tais observaçóes sobre a "inculturação" do canto de Jake são bastante superficiais, mas suficientes para mostrar as transformaçóes corporais exigidas 
por questóes técnicas (de gravação, nas relaçóes entre melodia, harmonia e ritmo) e comerciais (trata-se efetivamente da carreira profissional dela), que, no entanto, estáo englobadas pela vocação evangelizadora.

Também através das letras das músicas, Jake promove esta inculturação pop mediante outro deslizamento de sentidos amplo, usando referentes típicos da música baiana para ambientar a experiência cristã que ela está propondo. Estes referentes dizem respeito ao valor da alegria discutido anteriormente e descrevem sobretudo movimentos corporais da dança (girar, requebrar, jogar a máo para cima); relacionam-se também ao ambiente (paisagens e objetos) onde transcorrem as atividades musicais de Salvador (instrumentos musicais e ladeiras, por exemplo). Assim, o léxico e as práticas carnavalescas baianas se "convertem" em léxico e práticas de louvor cristáo.

Este movimento discursivo de "baianizar" e colocar axé em músicas católicas (que, no entanto, visam a um público mais abrangente) é algo relativamente novo no âmbito da chamada música gospel/religiosa. Isto porque os compositores geralmente aproveitam apenas o ritmo conhecido dos gêneros "pagãos", como forró, rock e funk, mas não dispensam as letras que contêm unicamente referentes cristāos, como é o caso de "I miss her/ Eu sou de Jesus", do irmáo Lázaro. Alguns exemplos de Jake, com paralelos (em itálico) no cancioneiro baiano/axé music:

Coração acelera, o timbal acompanha / Foi Jesus quem me sapecou (faixa 10, "Sapeca")

Leva, leva, leva, leva a levada do timbal (Timbalada, "Levada do Timbal")

Sobe ladeira no clima, espera Jesus passar (faixa 11, "Alê Alê") E me leva que eu vou amor, vou subindo a ladeira do Pelô (Banda Mel, "Ladeira do Pelô") 
Quebra, requebra / "Saculeja”, balança e "vambora" / Chegando Cristo / Bate o peito / Tá chegando a hora (faixa 13, "Quebra e Requebra")

O que é que a baiana tem? / Tem graça como ninguém / Como ela requebra bem (Dorival Caymmi, "O que é que a baiana tem")

Bata no peito mais forte e diga: eu sou ilê (Daniela Mercury, "Charme da Liberdade")

Excluindo "as músicas de protesto", que se constituíam de grandes narrativas exaltando a negritude e dando liçóes históricas complexas, as letras de axé music estão a serviço do ritmo (ver Guerreiro, 2000). O axé é feito para dançar e os conteúdos das músicas geralmente incentivam o movimento corporal, propondo coreografias e tratando de temas lúdicos e sensuais (embora questóes sociais e religiosas não estejam de todo ausentes em determinados artistas). Com tal intuito, muitos refrãos se constituem apenas de sequências silábicas formadas por sons onomatopaicos ou iniciadas por consoantes "plosivas", como o "p":

Pó pará com pó, pópópóparácompó (faixa 2, "Pó pará com pó”) Pê, pererêpê pêpêpê, pê pererê pê pêpêpê, pê (Ivete Sangalo, "Pererê") Piriripompom, piriri pompom, esse é o toque novo (Nwance, "Piriri Pompom")

Para que o álbum soasse como um disco de axé, além do naipe de percussão, dos ritmos baianos, da alteração prosódica e da relação entre forma/conteúdo das letras comentados acima, foi incluído o som de uma plateia virtual, que aplaude, grita e com quem Jake interage, como se fosse uma gravação ao vivo. $\mathrm{O} C D$ começa com uma saudação introdutória e prossegue com o encadeamento entre as faixas, seja musical ou através de comentários da cantora. No meio do "show", Jake prepara os ouvintes com um samba-reggae mais lento ("Baile lindo"), invoca a presença de Deus com a canção "Javé Chammá" ("Deus está aqui") e torna a apresentação um 
momento litúrgico com um misto de oração/testemunho (faixa 8, "Oração Deus te Abraça"), encerrado com uma espécie de Salmo do rei Davi (faixa 9, "Contemplar"). Neste momento, o movimento discursivo de dotar o Cristianismo de axé parece se inverter ao tornar o show de axé um tipo de celebração cristã. As músicas posteriores retomam a proposta efusiva.

Assim, a concepção e a realização do $\mathrm{CD}$ enfatizam a questão de se captar a experiência presente na gravação ao vivo, que é simulada para que se conte também com a qualidade técnica do registro em estúdio dos arranjos vocais e musicais. Mas a sensaçáo que se tem é a da inteireza de um show e de uma experiência religiosa, náo a de uma peça fragmentada em etapas e posteriormente montada que é o álbum composto por faixas produzidas de forma independente (embora tenha acontecido assim).

A repercussão do trabalho de Jake tem extrapolado o mundo católico, o que contraria teses como a de Brenda Carranza de que as atividades midiatizadas carismáticas tendem apenas a atingir os "de dentro" (2006). Em março de 2009, a cantora ganhou na categoria "marketing viral" do prêmio Melhores na Webesfera 2008 Youpix pelo vídeo campeão de acessos da já referida apresentação na TV Aparecida. Segundo dados fornecidos pela produção da cantora, o vídeo teve mais de 400 mil acessos em 10 dias. Conforme dito anteriormente, o trabalho de Jake foi citado em forma de desafio (aos outros cantores de axé) por Caetano Veloso em seu blog, Obra em Progresso: "quero 'pó pará com pó' cantado por Ivete, Daniela, Chiclete, Asa, Jamil e quem mais”.

Inicialmente através destas duas fontes, muitas pessoas que dificilmente se interessariam por música religiosa passaram a escutar Jake, levando-a a projetar a carreira em termos mais amplos. "Viajando por todo o Brasil fazendo shows em micaretas, em trios, palcos, ginásios, estádios, ruas, praças, a paulistana mais baianinha do Brasil pretende ampliar seu público além do meio católico e deseja que sua mensagem se propague", afirma o release da cantora para a imprensa.

Mas a receptividade extra e intra Igreja Católica não significa a ausência de percalços. Além de questóes aparentemente comerciais (como a distribuição e divulgaçáo do $\mathrm{CD}$, fator que distingue Jake de outros astros católicos como 
o Padre Fábio de Melo, que está apoiado em parcerias com grandes empresas do setor), há problemas de ordem eminentemente religiosa, que tem a ver com a mobilizaçáo de elementos alheios ao repertório católico-cristão por parte da cantora.

Jake conta que a exibição de sua participação gravada em determinada emissora católica foi cancelada sem qualquer explicação. "É uma pena, um comunicador cristáo a menos que eles náo quiseram mostrar", comenta, acrescentando que a mesma emissora traz conteúdos bastante repetitivos e solipsistas ("só sabem falar deles"). É bom lembrar que Jake tem formação em Comunicação Social - Publicidade e Propaganda. "Não queria usar meus conhecimentos para vender coisas em que eu não acredito", afirma. Todo o esquema de comunicaçáo em torno de Jake (sites, assessoria, produçáo) é bastante profissional e durante a entrevista ela demonstrou ter uma visão detalhada e crítica da atividade artística e midiática católica, incluindo as condiçóes mercadológicas envolvidas.

A outra dificuldade relatada por ela rendeu uma estratégia curiosa. Indaguei-lhe por que o CD tinha sido gravado parte em Caucaia, Ceará (instrumentos), e parte em Cachoeira Paulista (sede da comunidade Canção Nova, já referida antes no artigo), São Paulo (vocais). Ela conta que os músicos "pagáos" foram proibidos de entrar nos estúdios católicos. O resultado foi a gravação em estúdios diferentes. No entanto, os sons "pagáos" se juntaram posteriormente ao canto "sagrado" de Jake (ambos termos usados aqui no sentido particular do que estava autorizado ou náo a entrar no espaço santo da gravadora católica) através de técnicas de gravaçáo. Canto e instrumentos sáo comumente gravados em separado (temporalmente) e reunidos depois na produção da faixa, mas no caso de Guerreira do Amor isto ocorreu não exatamente por razóes técnicas, mas religiosas, e não só temporalmente, mas também espacialmente. Também não se pode falar apenas de reserva de mercado para músicos católicos. É bom ter em mente que os instrumentos percussivos do axé baiano e a maneira de tocá-los estáo intimamente ligados ao Candomblé. Neste caso, mixagem sonora e sincretismo se tornam sinônimos 
e explicitam o movimento de síntese pop-pagã/cristã-inculturada realizada pela cantora através de dispositivos tecnológicos.

Neste sentido, a posição estrutural liminar de Jake (sensus Tuner, 1974), como leiga, portanto fora da hierarquia romana, e de "espiritualidade carismática", sem pertencer formalmente a nenhuma comunidade da Renovação Carismática Católica brasileira, possibilita a liberdade para desenvolver o "talento" que lhe foi concedido: o carisma "desbravador e ousado" de cantar axé. Não se trata de tarefa fácil. Náo são apenas sacerdotes libertários que sáo alvos de sançóes por parte do Vaticano. Tanto o Padre Marcos Lázaro, que comanda a banda de axé Dom de Deus, como o Padre José de Souza Pinto, que dançou vestido de Oxum em missa inculturada para diferentes "raças", foram proibidos de celebrar missas pela Igreja Católica.

É importante dizer que as ações destes dois padres, importantíssimas no debate não só da inculturação católica, mas também da capacidade (e dos limites) do Cristianismo de se metamorfosear, são, no entanto, mais localizadas, e embora contassem com repercussáo nacional (no caso de Padre Pinto), o impacto maior se restringe a Salvador, nas paróquias onde eles presidiam como vigários (Piedade e Lapinha) e onde a presença negra justifica de maneira maior as apropriaçóes que eles tentaram trazer para o Catolicismo. Já o Padre Marcelo Rossi, uma das influências de Jake, que sempre que pode assiste a suas missas no Santuário do Terço Bizantino em Sáo Paulo, também foi considerado polêmico por subir em trios elétricos para cantar e conduzir multidóes em coreografias da sua "aeróbica do Senhor". A investidura sacerdotal parece conferir ao mesmo tempo legitimidade, destaque e limitação para a inovação religiosa, enquanto que os leigos podem se lançar em iniciativas mais livres, porém com menor respaldo institucional (incluindo aqui cobertura midiática, parcerias com empresas de comunicação e mesmo atenção inicial do público).

A atuaçáo de Jake, que pessoalmente discorda de "extremos" como o balé de Padre Pinto, é literalmente "rizomática" (Deleuze; Guatarri, 1994), pois acontece de igual maneira nas redes de comunicação e nas apresentaçóes presenciais. A cantora também se vale da máscara carnavalesca (de cantora 
baiana de trio elétrico), pródiga para as combinaçóes entre o sagrado e o pagáo/profano e para a crítica alegre ao formalismo sisudo e enrijecido das instituiçōes (ver Bakhtin, 1999).

A maior parte dos trabalhos sobre a Antropologia do Cristianismo focaliza a maneira pela qual tal sistema religioso, transmitido por missionários euro-americanos, se particulariza a partir da cultura de determinados grupos. Autores como Joel Robbins acrescentam também a questão de como o Cristianismo entra nos próprios processos de mudança cultural dos coletivos cristianizados, diante de novas questóes trazidas pelo contato e a globalizaçáo. No Brasil, a Antropologia do Cristianismo que toma o material melanésio como referência busca situaçóes muito próximas das trabalhadas pelos agentes formais de inculturação católica, que no aspecto missionário se dedicam, sobretudo, aos grupos indígenas. Mas a Cristianização, afinal de contas, só acontece com povos nativos e através de missionários coloniais? A resposta é negativa, tanto para agentes como pacientes, principalmente porque o evangelizado tem que se tornar evangelizador no processo de tornar-se cristáo.

Ao tomar o trabalho de Jake como estudo de caso de açáo evangelizadora, quis ampliar o enfoque nativizador, quase étnico, da cristianização para mostrar que, ao menos do ponto de vista do Cristianismo (católico ou não), as diferenças culturais que demandam criatividade na transmissão da mensagem religiosa sáo variadas e tendem a se equivaler, pois exigem soluçóes discursivas (linguísticas, comunicacionais, melódicas, visuais e corporais) complexas tanto no caso dos nativos "nativos" como no outro, dos diversos públicos-alvos possíveis da evangelizaçáo cristã e que náo são exóticos o suficiente para a antropologia a ponto de se dizer que eles estáo sendo também "cristianizados".

Mas Jake também está lidando com a indigenização do Cristianismo para o contexto brasileiro, sobretudo através de referências pop que por sua vez remetem, ora de maneira difusa, ora de forma bem explícita, a questóes da formação histórica do país e símbolos mais ou menos estabilizados da convenção conhecida como "nacionalidade brasileira". Ao mesmo tempo 
em que se apropria da música regional da Bahia, a cantora também está evocando o arquétipo feminino da brasilidade: a baiana.

O discurso visual fundante da baiana acontece com Carmen Miranda, que começa a fazer sucesso no Brasil no final da década de 1920 e chega a ser a artista mais bem paga de Hollywood na década de 1940. Todas as ambiguidades possíveis estão presentes na carreira e na representação do Brasil incorporada em Carmen Miranda (é impossível tratar delas aqui), mas o estatuto da bricolagem realizada por ela continuaria válido como mostra da disposiçáo criativa do povo e do artista brasileiros, de acordo com as principais tentativas de achar a essência nacional do Brasil. $\mathrm{O}$ mais interessante é que a "Brazilian Bombshell" era uma "falsa baiana", como Jake: nasceu portuguesa, vivia no Rio de Janeiro e se consagrou mundialmente como baiana estilizada, ou seja, fruto de uma elaboração criativa, nos Estados Unidos.

Antes de Carmen, a figura da baiana já ocupa certo espaço no imaginário nacional forjado a partir do Rio de Janeiro. As baianas migrantes vão ser fundamentais para a difusáo dos cultos e da musicalidade afro-brasileiros na capital imperial e depois federal, sendo Tia Ciata a representante emblemática deste momento. "A venda de cocadas e acarajés costumava ser apenas a fachada legal dessas senhoras gordas e joviais que, na verdade, eram as líderes religiosas de suas comunidades no entorno da Praça Onze. Essa religião, naturalmente, era o Candomblé. Mas elas eram também animadoras dos sambas e choros que tocavam em suas casas", descreve assim Ruy Castro a participaçáo das baianas na vida cotidiana carioca da época $(2005, \text { p. } 71)^{11}$.

No entanto, segundo o autor, as baianas abandonaram o esplendor do vestuário ao chegar às terras fluminenses, sobretudo os adereços de ouro e prata. Mas permanecem certos traços como a brancura dos vestidos, cor que

11 Outra contextualizaçáo importante sobre a presença da baiana no momento do surgimento do samba e da cultura carnavalesca no Rio de Janeiro durante a passagem do Império para a República e sobre a repercussáo dos acontecimentos artísticos do período para os debates posteriores sobre a identidade nacional (realizados no contexto da Semana de Arte Moderna de 1922 e da noção de povo brasileiro criada no Estado Novo) está em $O$ Mistério do Samba, de Hermano Vianna (2005).

Debates do NER, Porto Alegre, ano i6, N. 28, P. 37-68, Jul./Dez. 20 i 5 
remete tanto a Oxalá quanto à prescrição higienista exigida para o trabalho com o público das filhas de São Salvador como vendedoras de quitutes. Logo o traje de baiana se torna fantasia carnavalesca, associada a folióes mais pobres. Como forma de figurar em números artísticos para plateias mais refinadas, a fantasia de baiana deveria ser estilizada.

Desde o começo da carreira, Carmen estava sintonizada com a Bahia, pois o repertório da artista incluía inúmeras cançóes alusivas ao estado, muitas de autoria de Ary Barroso. No entanto, os elementos marcantes do visual estético e cinético de Carmen Miranda e da baiana vão se conformar através da performance dela no filme Banana da Terra (1938/39), cantando o primeiro sucesso do baiano Dorival Caymmi, "O que é que a baiana tem?".

Carmen, que era também grande costureira e criava as próprias roupas e acessórios, seguiu a lista de itens enumerada por Caymmi para compor a indumentária completa da baiana que seria seu figurino no filme. A maior inovação, segundo Castro, foi a recuperação dos balangandâs. "Os balangandãs eram pencas de figa e amuletos de metais nobres, lavrados por finos ourives, e de quaisquer objetos de ferro, madeira ou osso que representassem um pedido ao santo ou o pagamento de uma promessa" (2005, p. 170). "Um rosário de ouro, uma bolota assim, quem não tem balangandâs não vai no Bonfim", nas palavras de Caymmi, que também coreografa os trejeitos e dengos baianos de Carmen Miranda. A síntese realizada por Carmen continua sendo retomada, como, por exemplo, no show Canibália (2009) de Daniela Mercury, uma das referências musicais de Jake.

Os balangandãs integram um complexo de objetos africanos protetores que, no Brasil, adquirem também caráter devocional e mesmo terapêutico com a incorporação de referências cristâs, e que incluem ainda as bolsas de mandinga (Meyer, 1999, também fala de prática similar entre os Ewe, recebida dos Yorubá. Como a doença é um sinal do mal para estes povos, objetos protetores podem também ter propriedades curativas). A cantora potencializa as qualidades estéticas e sonoras da tilintante, vistosa, mas também profundamente numinosa composição que incluía ainda pulseiras, brincos, rendas e outros apetrechos. 
Tal exuberância também está presente nos trajes de Jake, tanto no palco e em fotos promocionais como em outras situaçóes mais cotidianas. Durante a entrevista realizada na casa dela em Sáo Paulo, me chamaram a atenção as grandes argolas e a profusão de pulseiras e braceletes, que se chocavam enquanto ela gesticulava nas respostas, tornando toda a conversa sonora. Abaixo, o deslizamento de sentido realizado pela cantora a partir do referencial imagético comentado acima, operando a transformação visual de Jake na "paulistana mais baianinha do Brasil":

Figura 1 - Deslizamento de sentidos entre imagens da baiana

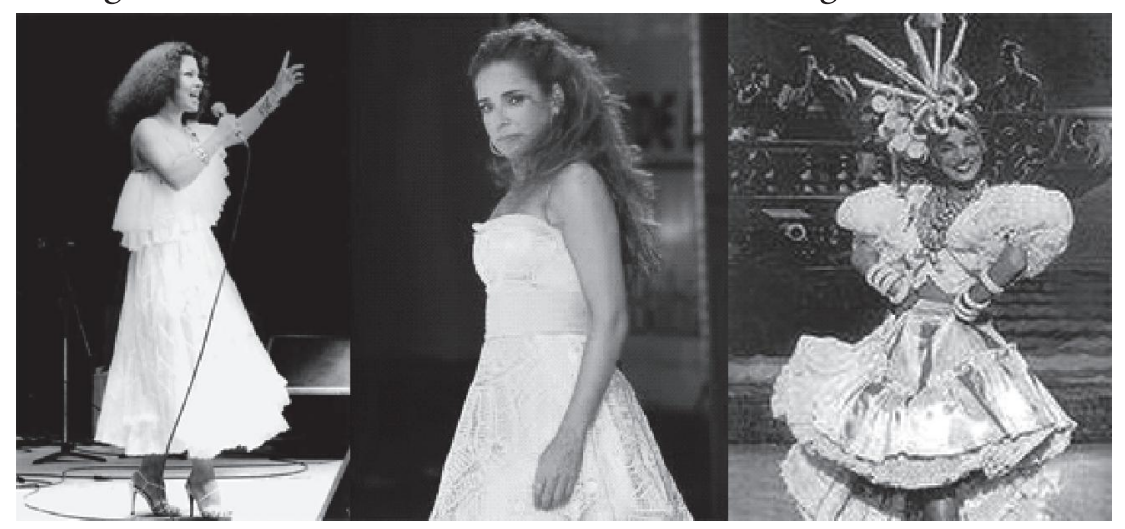

Clara Nunes, Daniela Mercury e Carmen Miranda 
Fotos 3 e 4 - Imagens do website de Jake que mostram a cantora "inculturada" de baiana

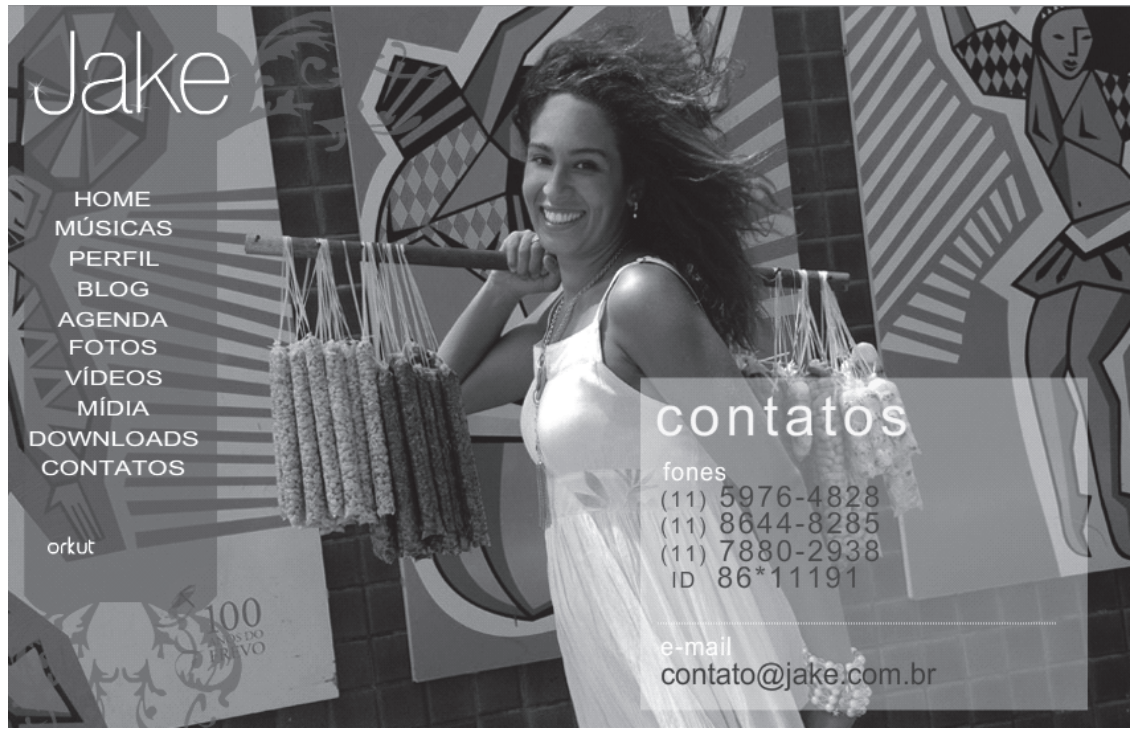

Vestido branco, colar, pulseiras e canga (substituindo o tabuleiro) da baiana vendedora ambulante de iguarias. No fundo, azulejos com motivos carnavalescos.

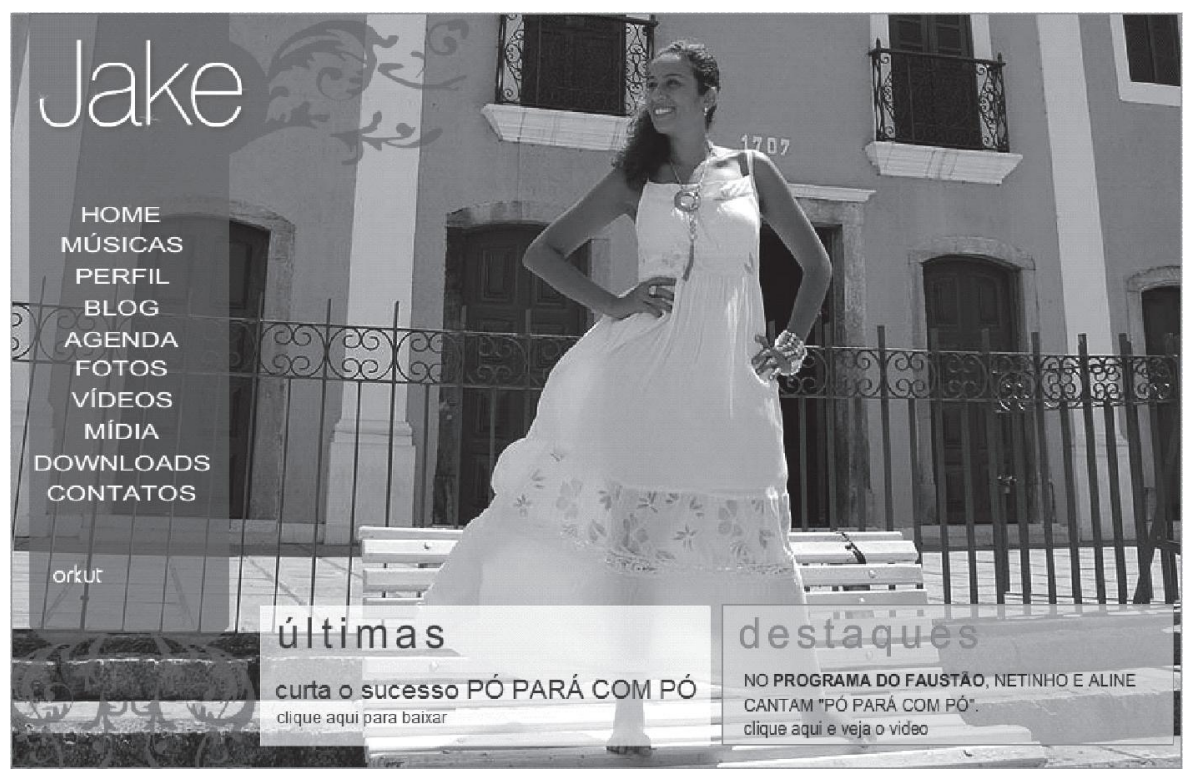

Pele escura contrastando com a alvura do vestido, balangandá no pescoço. Pulseiras de metal tilintante. Ao fundo, construçáo de estilo colonial, paisagem de onde se decalcam as iaiás da Bahia para figurar no imaginário nacional. 
Outro aspecto interessante do visual de Jake merece ser comentado. A cantora costuma se apresentar descalça (como no Programa do Jô exibido em 08/05/2009). Há uma linhagem de nomes da música popular brasileira, que inclui Clementina de Jesus, Maria Bethânia e Clara Nunes, todas ligadas à Umbanda e ao Candomblé, que costumam se apresentar assim. Pessoas com pés calçados não podem entrar nos espaços sagrados destes cultos afro-brasileiros.

O pop aparece aqui mais uma vez como fonte de empréstimo indireta de significantes visuais/performáticos de um complexo simbólico de circulaçáo nacional, mas que tem ligaçóes traçáveis com repertórios mais localizados e náo facilmente assimiláveis por instâncias como o Cristianismo. A axé music é um caso bem-sucedido de empreendimento musical que começa de forma localizada, mas que alcança (através de carnavais fora de época, shows e apariçóes midiáticas) um estatuto nacional. Isto acontece através da ressignificação e atualização de símbolos costumeiramente utilizados nos discursos de brasilidade, mas que dizem respeito a personagens, ritmos, paisagens, motivaçóes e temas particulares à Bahia. Jake mobiliza este fluxo cultural em nome de uma evangelizaçáo mais ampla, alegre e inovadora.

\section{CONCLUSÃO}

Diante de tal quadro, parece difícil chegar a conclusóes como a de Marjo Theije e Cecília Mariz sobre a questão da inculturação no Catolicismo brasileiro:

In Brazil the MRCC [movimento da renovaçáo carismática católica] has avoided discussing the tensions between the universal and local values, and it presents itself as a universal or global discourse. For the MRCC, debates on acculturation seem to be an absolute nonissue: the theme is absent from the movement's publication, inculturation is neither discussed nor reflected upon, and there is no discussion about ethnic identity or culture (2008, p. 41).

A avaliação das autoras demonstra a necessidade de obter conhecimentos mais amplos sobre a diversidade dos fatos etnográficos relativos à Renovaçáo 
Carismática no Brasil, bem como de revisar certas tradiçōes acadêmicas sobre o tema que fazem com que o fenômeno não seja analisado por si, mas com base em outro referencial religioso considerado, por exemplo, mais politizado. O mais recorrente é a comparação da proposta carismática com a da Teologia da Libertaçáo, principalmente a tensa relaçáo desta com a Teologia da Inculturação, que náo tem conseguido conciliar a promoção da diversidade cultural com a incorporaçáo dos conteúdos originados dos povos náo ocidentais como fonte de inovação para a mensagem fundamental cristá (Rufino, 2002, p. 313). Assim, o problema náo está na comparaçáo em si, mas na escolha da abordagem de tal vertente católica como parâmetro para as definiçóes do que é "popular" e "local" e em como trazer tais elementos para as iniciativas cristấs.

A perspectiva da Teologia da Libertação, endossada pelas autoras, remete o popular e o local às manifestaçóes artísticas de grupos oprimidos em termos sociais, políticos e econômicos, que por ocupar tal posição se expressariam através de artefatos culturais "autênticos", em contraposiçáo aos bens simbólicos provenientes da produçáo massiva. Isto acaba deixando de lado o popular e o local em ritmos musicais de grande apelo comercial, como a axé music. Não é preciso nem apontar para a base rítmica do afoxé e a temática de resistência negra existentes nos primórdios do estilo musical baiano, pois o ritmo continua sendo consumido em larga escala em todo o país, sendo, portanto, popular no sentido de atingir parte considerável da populaçáo brasileira que reconhece o imaginário visual e musical e a coloquialidade linguística promovida pelo axé. É precisamente tal imaginário, bem com tal marco linguístico, a referência da cantora Jake para adaptar a mensagem cristấ católica. "Tornar-se tudo para com todos" é algo que os evangelizadores cristáos tomam como premissa para o trabalho que realizam. 


\section{REFERENNCIAS}

AUSTIN-BROOS, Diane J. Jamaica Genesis: Religion and the Politics of Moral Orders. Chicago: University of Chicago Press, 1997.

BAKTHIN, Mikail. A Cultura Popular na Idade Média e no Renascimento: o contexto de François Rabelais. São Paulo: Hucitec; Brasília: UnB, 1999.

BLOOM, Harold. What is Religious Criticism? In: . American Religion: the emergence of the post-christian nation. New York: Simon \& Schuster, 1992. BONFIM, Evandro. Canção Nova: circulação de dons, mensagens e pessoas espirituais em uma comunidade carismática. 2012. 397 f. Tese (Doutorado em Antropologia Social) - Museu Nacional, Universidade Federal do Rio de Janeiro, Rio de Janeiro, 2012.

BROWN, Peter. A Ascensão do Cristianismo no Ocidente. Lisboa: Editorial Presença, 1999.

CANNEL, Fenella. The Christianity of Anthropology. The Journal of the Royal Anthropological Institute, v. 11, n. 2, p. 335-356, 2005.

CARRANZA, Brenda. Catolicismo Midiático. In: TEIXEIRA, Faustino; MENEZES, Renata (Org.). As Religióes no Brasil: continuidades e rupturas. Petrópolis: Vozes, 2006.

CASTRO, Ruy. Carmen: uma biografia. Sáo Paulo: Companhia das Letras, 2005.

CONFERENCIA NACIONAL DOS BISPOS DO BRASIL. Pastoral Afro-Brasileira. São Paulo: Paulus, 2002.

DELEUZE, Gilles; GUATTARI, Félix. Introdução: Rizoma. In: Mil Platôs: capitalismo e esquizofrenia (vol. 1). Sáo Paulo: Editora 34, 1995. FONSECA, Alexandre Brasil. Fé na tela: características e ênfases de duas estratégias evangélicas na televisão. Religiāo e Sociedade, Rio de Janeiro: Iser, v. 23, n. 2, p. 33-52, 2003. 
GUERREIRO, Goli. A Trama dos Tambores: a Música Afro-Pop de Salvador. Sáo Paulo: Editora 34, 2000.

HARDING, Susan. Representing fundamentalism: the problem of the repugnant other. Social Research, v. 58, n. 3, p. 373-393, Fall 1991.

KELLER, Eva. Scripture study as normal science: Seventh-Day Adventist practice on the East Coast of Madagascar. In: CANNEL, Fenella (Ed). The Anthropology of Christianity. Durham; London: Duke University Press, 2006. LATOUR, Bruno. "Não congelarás a imagem", ou: como não desentender o debate ciência-religiáo. Mana: Estudos de Antropologia Social, v. 10, n. 2, p. 349-376, 2004.

MEYER, Birgit. Translating the Devil: Religion and Modernity among the Ewe in Ghana. Trenton: African World Press, 1999.

. Religious sensations: why media, aesthetics and power matter in the study of contemporary religion. In: VRIES, Hent de. Religion: beyond a concept. New York: Fordham University Press, 2008.

MIRANDA, Mario de França. Inculturaçāo da Fé: uma abordagem teológica. Sáo Paulo: Loyola, 2001.

MOSKO, Mark. Partible Penitents: Christianity and Dividual Personhood in Melanesia and the West. Journal of the Royal Anthropological Institute, v. 16, n. 2, p. 215-240, June 2010.

PAULO VI. Exortação Apostólica "Evangelii Nuntiandi" sobre a Evangelização no Mundo Contemporâneo. São Paulo: Paulinas, 2006 [1975].

ROBBINS, Joel. Becoming Sinners: Christianity and Moral Torment in a Papua New Guinea Society. Berkeley: University of California Press, $2004 a$. . The Globalization of Pentecostal and Charismatic Christianity. Annual Review of Anthropology, v. 33, p. 117-143, Oct. 2004b. 
. Continuity Thinking and the Problem of Christian Culture: Belief, Time and the Anthropology of Christianity. Current Anthropology, v. 48, n. 1, p. 5-38, Feb. 2007.

RUFINO, Marcos Pereira. "Ide, portanto, mas em silêncio": faces de um indigenismo católico heterodoxo. 2002. Tese (Doutorado em Antropologia Social) - Universidade de São Paulo, São Paulo, 2002.

SAHLINS, Marshall. The sadness of sweetness: the native anthropology of Western cosmology. Current Anthropology, v. 37, n. 3, p. 395-415, 1996.

SILVA, Vagner Gonçalves. Neopentecostalismo e Religióes Afro-Brasileiras: Significados do Ataque aos Símbolos da Herança Religiosa Africana no Brasil Contemporâneo. Mana: Estudos de Antropologia Social, v. 13, n. 1, p. 207-236, 2007.

SOUZA, André Ricardo. Igreja in concert: padres cantores, mídia e marketing. São Paulo: Annablume; Fapesp, 2005.

THEIJE, Marjo de; MARIZ, Cecília Loreto. Localizing and Globalizing Processes in Brazilian Catholicism: Comparing Inculturation in Liberationist and Charismatic Catholic Cultures. Latin American Research Review, v. 43, n. 1, p. 33-54, 2008.

TURNER, Victor. O Processo Ritual. Petrópolis: Vozes, 1974.

VIANNA, Hermano. O Mistério do Samba. Rio de Janeiro: Zahar, 2005.

Recebido em: 30/08/2015

Aprovado em: 17/09/2015 